Arch. Tierz., Dummerstorf 49 (2006) 4, 340-350

Mendel University of Agriculture and Forestry Brno, Czech Republic

JAN ŠUBRT, RADEK FILIPČÍK, ZDENĚK ŽUPKA, MILADA FIALOVÁ and ELIŠKA DRAČKOVÁ

\title{
The content of polyunsaturated fatty acids in intramuscular fat of beef cattle in different breeds and crossbreeds*
}

\begin{abstract}
The effect of crossbreeding on the content of polyunsaturated fatty acids (PUFA) in intramuscular adipose tissue of the Musculus longissimus pars thoracis of slaughter bulls was studied. The differences among 8 genotypes of bulls was most significant $(\mathrm{p}<0.01)$ in C18:3, C20:4, C22:4, C22:5 and C22:6. The content of linolenic acid (C18:3) in the Czech Spotted Cattle (control group) was 0.526\%, the highest in the Czech Spotted $\mathrm{x}$ Piedmont cattle crosses (0.659\%), and the lowest in crosses with the Belgian breed $(0.186 \%)$. We evaluated the content of C18:3 (n-6 and n-3) and among the genotypes the differences in the content were insignificant. Compared with the control group all the evaluated genotypes showed a higher representation of C18 n-3, which does not apply to the isomer C18 n-6. At low percent values we detected insignificant differences in changes in content of isomers C22:5. Factors such as the age of the animals and the carcass weight had no effect on the structure of fatty acids. More important was the content of the intramuscularly adipose tissues. With increasing content of intramuscularly adipose tissue the values of C18:3 (n-3 and n-6) and C22:5 (n-3 and n-6) decreased as did the content of other acids belonging to PUFA $(\mathrm{p}<0.01)$.
\end{abstract}

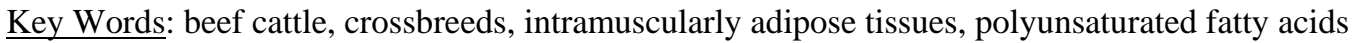

\section{Zusammenfassung}

Titel der Arbeit: Die Struktur mehrfach ungesättigter Fettsäuren im intramuskulären Fett von Mastbullen bei verschiedenen Fleischrinderrassenkreuzungen

Untersucht wurde der Einf1uss des Genotyps auf den Gehalt mehrfach ungesättigter Fettsäuren (PUFA) im Musculus longissimus thoracis bei acht Fleischrinderrassenkreuzungen. Die Unterschiede bei C 18:3, C 20:4, C 22:4, C 22:5 und C 22:6 zwischen den Genotypen waren signifikant $(\mathrm{p}<0,01)$. Bei der Kontrollgruppe, dem Tschechischen Fleckvieh lag der Gehalt an Linolensäure bei 0,526 \%. Bei den Kreuzungstieren fand sich der höchste bei der Gruppe Fleckvieh x Piemonteser (0,659 \%) der niedrigste bei Fleckvieh x Weißblaue Belgier (0,186 \%). Der Gehalt an C 18:3 (n-6 und n-3) innerhalb der Genotypen war nicht signifikant. Verglichen mit der Kontrollpopulation zeigten die Kreuzungsgruppen höhere Gehalte an C 18: 3 n-3 was nicht für C 18 n-6 zutraf. Faktoren wie das Alter oder das Schlachtgewicht der Tiere hatten keinen nachweisbaren Einfluss auf die Struktur der untersuchten Fettsäuren. Bedeutsamer war das intramuskuläre Fett im Muskelgewebe. Mit seiner Erhöhung ging eine signifikante Verringerung der Werte für C 18:3 (n-3 und n-6) sowie C 22:5 (n-3 und n-6) ebenso wie bei den anderen PUFA Fettsäuren $(p<0,01)$ einher.

Schlüsselwörter: Fleischrinderrassen, Kreuzung, intramuskuläres Fett, mehrfach ungesättigte Fettsäure

\section{Introduction}

In this scientific area a number of studies were devoted to the effects on changes in the content of fatty acids. Most of them were devoted to methods, which would improve the content of fatty acids by applying diets of various compositions and different levels of intensity in the nutrition of slaughter cattle (PALANSKÁ et al., 1993; KREUZER et al., 1996; MATTHES et al., 1996; LEIBETSEDER, 1996; STEEN et al., 2003; RAES et al., 2003; HOLLO et al., 2005). According to results of recent studies (SAMI et al., 2004) the ratio of polyunsaturated to saturated fatty acids (PUFA: SFA) during 
intensive nutrition of feeding. The composition of fatty acids in meat is also influenced by genetic factors, but to a lesser extent that dietary factors. All the same we can consider the kinds of meat as a more important source of changes in the fatty acid composition (De SMET et al., 2004). A number of studies (ENDER et al., 1997; PFEUFFER, 2001; RAES et al., 2004) elaborated on how to maintain and improve the consumer's health, the aim of which was to determine the possibility of increasing the proportion of unsaturated fatty acids, particularly long-chain n-3 acids, in the intramuscularly adipose tissue of beef, lamb and pork. In most of these studies the increased proportion of n-3 acids in intramuscularly adipose tissue was accompanied by a decreased deposition of $n-6$ resulting in a much better $n-6 / n-3$ ratio, while the unsaturated / saturated ratio (PUFA/SFA) was lees affected. According to WOOD et al. (2004) the interest in improving the proportion of fatty acids in meat is essentially based on the need to find a way of producing healthy meat with a higher ratio of polyunsaturated (PUFA) to saturated (SFA) acids and better balance between the PUFA n-6 and n-3. The meat of ruminants is a relatively good source of PUFA n-3 due to the presence of 18:3 in grass.

Less attention in the published studies was devoted to the effect of other factors of animal husbandry; such as different breeds and commercial types, slaughter weight, age of animals at slaughter, and the total content of intramuscularly adipose tissue on changes in the profile of fatty acids. A number of authors have recently to a greater or lesser extent studied the effects of these factors on targeted regulation of the content of fatty acids in beef (ŠUBRT et al., 1991; RULE et al., 1997; MOJTO et al., 1998; FRELICH et al., 1998; LABORDE et al., 2001; ŠUBRT et al., 2001; CHAMBAZ et al. 2001; OPRZADEK et al., 2003 and DANNENBERGER et al., 2004). Also the level of fat production affects the composition of fatty acids (De SMET et al., 2004). Depending on the increasing fat content, the content of saturated (SFA) and monounsaturated (MUFA) acids increases faster than the PUFA content. This could be associated with the capacity of the breeds and cattle genotypes to deposit intramuscularly adipose tissue.

\section{Material and Methods}

For evaluations of the profile of unsaturated fatty acids we used crosses of cows of Czech Spotted cattle (C) with bulls of specialised beef breeds, i.e. Aberdeen Angus (Aa), Aquitaine Blond (Ba), Belgian Blue (Bb), Charolais (Ch), Limousine (Li), Hereford (He) and Piedmont (Pi). The control group was bulls of the domestic dualpurpose cattle, i.e. Czech Spotted (C). Over the whole period of fattening the feed ration of the slaughter bulls was made up for the individual age categories and was based on preserved roughage (maize silage, alfalfa hay) with an additive of concentrates to balance the content of necessary nutrients and mineral supplements. The feed ration for bulls was made for the respective growth categories according to the uniform methods of progeny testing, and bull fattening was carried out under the same housing conditions, i.e. in one stable. During fattening the components of the feed ration were not analysed for the content of fatty acids. At the end of the fattening period the animals were slaughtered at the average age of 500 days and slaughter weight $570 \mathrm{~kg}$. Table 1 shows the structure of the group of bulls according to their genotype.

Fatty acid analysis were conducted in 221 samples taken from the longissimus pars 
thoracis muscle at the $9^{\text {th }}-10^{\text {th }}$ thoracic vertebrae. Only the n- 3 and n- 6 acids were determined in fewer animals (102 head) - control group of 18 bulls and duodenary bull beef genotypes /12 bulls each/.

The extracted muscle fat was esterified and after conversion to methyl esters of fatty acids was analyzed on a CHROM 5 gas chromatograph with flame ionizing detector (PID). The analyzed fatty acids were identified on the basis of elution times and compared with elution times of standard methyl esters of fatty acids. The CI-105 integrator was used for quantitative evaluations of chromatographic analysis. The result of the evaluations is the percentage content of the fatty acids. In the present study the focus was on the analysis of the content of polyunsaturated fatty acids with three and more carbons in the chain. In part of the samples we also evaluated the content of isomers n-6 and n-3 of linolenic acid and docosapentaenic acid (DPA), i.e. according to the position of the first double bond from the end methyl group.

For mathematic-statistical evaluations of the selected factors we used the method of multi-factor analysis of variance (ANOVA) in the SAS 8.1 programme.

$$
Y_{i j k l m}=\mu+G_{i}+A_{j}+C W_{k}+F_{l}+e_{i j k l m}
$$

$\mathrm{G}_{\mathrm{i}}=$ Genotype (1-8), $\mathrm{A}_{\mathrm{j}}=$ age of slaughter bulls ( $<500$ day / $>501$ day), $\mathrm{CW}_{\mathrm{k}}=$ carcass weight $(<310 \mathrm{~kg} / 311-350 \mathrm{~kg} />351 \mathrm{~kg}), \mathrm{F}_{1}=$ percentage content of intramuscularly fatty $(<1.0 \% / 1.1-2.0 \% />2.1 \%)$, $\mathrm{e}_{\mathrm{ijk} k \mathrm{~m}}=$ residue. Significant differences in the individual factors were seen among the groups $(\mathrm{p}<0.05 / \mathrm{p}<0.01)$.

Table 1

Basic characteristics of the group of slaughter bulls (Beschreibung der geschlachteten Versuchsbullengruppen)

\begin{tabular}{|c|c|c|c|c|c|}
\hline $\begin{array}{l}\text { Genotype } \\
\text { position }\end{array}$ & Genotype /* & $\begin{array}{c}(\mathrm{N}=221) \\
\mathrm{n}\end{array}$ & $\begin{array}{l}\text { Slaughter age } \\
\text { (days) }\end{array}$ & $\begin{array}{c}\text { Carcass weight } \\
\text { (kg) }\end{array}$ & $\begin{array}{c}\text { Intramuscular } \\
\text { fat (\%) }\end{array}$ \\
\hline 1 & $\mathrm{C}$ & 39 & 550 & 378 & 2.00 \\
\hline 2 & $\mathrm{C} \times \mathrm{Aa}$ & 19 & 501 & 322 & 1.65 \\
\hline 3 & $\mathrm{C} \times \mathrm{Ba}$ & 18 & 479 & 329 & 1.05 \\
\hline 4 & $\mathrm{C} \times \mathrm{Bb}$ & 10 & 500 & 322 & 1.06 \\
\hline 5 & $\mathrm{C} \times \mathrm{He}$ & 12 & 489 & 300 & 2.15 \\
\hline 6 & $\mathrm{C} \times \mathrm{Ch}$ & 67 & 500 & 341 & 1.17 \\
\hline 7 & C x Li & 33 & 481 & 318 & 1.11 \\
\hline 8 & $\mathrm{C} \times \mathrm{Pi}$ & 23 & 500 & 330 & 1.02 \\
\hline Average & & & $500 \pm 0.315$ & $330 \pm 3.441$ & $1.40 \pm 0.059$ \\
\hline
\end{tabular}

*/C - Czech Spotted Cattle (Control group), Aa - Aberdeen Angus, Ba - Blond Aquitaine,

$\mathrm{Bb}$ - Belgian Blue, He - Hereford, Ch - Charolais, Li - Limousine, Pi - Piedmont

\section{Results}

To study the effect of biological factors on differences in the content of the fatty acids in muscles of slaughter bulls we singled out four fixed effects, i.e. the genotype, age at the time of slaughter, carcass weight, and content of intramuscularly adipose tissue in m.l.th.

Tables 2, 3 and 4 give the results of analysis of the effect of 8 genotypes of bulls on the content of the fatty acids. The content of polyunsaturated fatty acids was most significant when observing changes in the content of C18:3, C20:4, C22:4, C22:5 and C22:6. The content of C18:3 was the highest in Piemontese crossbreds (0.659 \pm $0.054 \%)$ and the lowest in the Belgian crossbreds $(0.186 \pm 0.067 \%)$. The content of linolenic acid was relatively high in the control group (Table 2). Differences in the 
content of fatty acid C20:3, numbered as a PUFA, among the genotypes are significant particularly at the $\mathrm{p}<0.05$ level.

Table 2

Content of polyunsaturated fatty acids (C18-20) in meat of bulls according to the genotype (\%) (Gehalt mehrfach ungesättigter Fettsäuren /C18-20/ im Bullenfleisch nach Genotypen in \%)

\begin{tabular}{|c|c|c|c|c|}
\hline \multirow{2}{*}{ Genotype position /* } & \multirow{2}{*}{ Fatty acids } & \multirow{2}{*}{$\mathrm{LS}$ mean $\pm \mathrm{SE}$} & \multicolumn{2}{|c|}{ Statistical significance } \\
\hline & & & $\mathrm{p}<0.05$ & $\mathrm{p}<0.01$ \\
\hline 1 & & $0.526 \pm 0.064$ & - & $2,3,4,6,7$ \\
\hline 2 & & $0.291 \pm 0.051$ & - & $1,4,5,7,8$ \\
\hline 3 & & $0.265 \pm 0.041$ & - & $1,5,7,8$ \\
\hline 4 & & $0.186 \pm 0.067$ & - & $1,2,5,7,8$ \\
\hline 5 & C18:3 & $0.549 \pm 0.075$ & - & $2,3,4,6$ \\
\hline 6 & & $0.291 \pm 0.024$ & - & $1,5,7,8$ \\
\hline 7 & & $0.528 \pm 0.039$ & 8 & $1,2,3,4,6$ \\
\hline 8 & & $0.659 \pm 0.054$ & 7 & $2,3,4,6$ \\
\hline 1 & & $0.142 \pm 0.019$ & $2,3,6$ & - \\
\hline 2 & & $0.092 \pm 0.015$ & 1,8 & - \\
\hline 3 & & $0.081 \pm 0.012$ & $1,7,8$ & - \\
\hline 4 & & $0.072 \pm 0.019$ & 8 & - \\
\hline 5 & C20:3 & $0.123 \pm 0.022$ & - & - \\
\hline 6 & & $0.079 \pm 0.007$ & 1,7 & 8 \\
\hline 7 & & $0.125 \pm 0.011$ & $3,6,8$ & - \\
\hline 8 & & $0.149 \pm 0.016$ & $2,4,7$ & 6 \\
\hline 1 & & $0.346 \pm 0.068$ & - & 3,4 \\
\hline 2 & & $0.377 \pm 0.054$ & - & 8 \\
\hline 3 & & $0.349 \pm 0.089$ & 6 & $1,7,8$ \\
\hline 4 & & $0.451 \pm 0.085$ & 7 & 1,8 \\
\hline 5 & C20:4 & $0.380 \pm 0.100$ & - & 6 \\
\hline 6 & & $0.257 \pm 0.032$ & 3 & $5,7,8$ \\
\hline 7 & & $0.381 \pm 0.051$ & 4 & 3,6 \\
\hline 8 & & $0.584 \pm 0.072$ & - & $2,3,4,6$ \\
\hline 1 & & $0.112 \pm 0.016$ & - & - \\
\hline 2 & & $0.131 \pm 0.013$ & - & - \\
\hline 3 & & $0.125 \pm 0.021$ & - & 8 \\
\hline 4 & & $0.092 \pm 0.020$ & - & - \\
\hline 5 & C $20: 5$ & $0.126 \pm 0.024$ & - & - \\
\hline 6 & & $0.119 \pm 0.007$ & 8 & - \\
\hline 7 & & $0.110 \pm 0.012$ & - & - \\
\hline 8 & & $0.074 \pm 0.017$ & 6 & 3 \\
\hline 1 & & $0.037 \pm 0.005$ & - & - \\
\hline 2 & & $0.042 \pm 0.004$ & 6 & 5 \\
\hline 3 & & $0.043 \pm 0.007$ & 5 & - \\
\hline 4 & & $0.042 \pm 0.006$ & - & - \\
\hline 5 & C20:6 & $0.061 \pm 0.008$ & 3 & 2 \\
\hline 6 & & $0.050 \pm 0.002$ & 2 & - \\
\hline 7 & & $0.044 \pm 0.004$ & - & - \\
\hline 8 & & $0.048 \pm 0.005$ & - & - \\
\hline
\end{tabular}

*/ See table 1

The highest content was determined in bulls - Piemontese crossbreds (0.149\%), while the lowest values were quantified in crosses with the Belgian Blue, Charolais and Aquitaine Blond. The differences between the highest and lowest values were statistically significant $(\mathrm{p}<0.01)$. The differences in the content of fatty acid with the same number of carbons but higher number of double bonds (C20:4) were significant and dependent on the genotypes of the slaughter bull. The most significant $(p<0.01)$ 
genotype differences were seen among Charolais hybrid bulls and $\mathrm{C} x$ Pi. The differences between the control group $\mathrm{C}$ with the $\mathrm{C} \times \mathrm{Bb}$ and $\mathrm{C} \times \mathrm{Ba}$ were also significant $(\mathrm{p}<0.01)$. The content of fatty acid C20:5 was the lowest in $\mathrm{C} \times \mathrm{Pi}$ crossbreds and the significantly highest values were quantified in $\mathrm{C} \mathrm{x}$ Ba crossbreds. The differences in the content of fatty acid C20:6 among the genotypes were less significant; the highest in $\mathrm{C} x$ He crossbreds and the lowest in C x Aa crossbreds.

The differences in the content of long-chain carbon fatty acids C22:4, C22:5 and C22:6 were significant to highly significant (Table 3 ). When analyzing the changes in the content of fatty acid C22:4, the highest significant value $(\mathrm{p}<0.01)$ was quantified in the Pi-hybrids and the minimal values in $\mathrm{C} x$ He crossbreds.

Table 3

Content of polyunsaturated fatty acids (C22) in meat of bulls according to the genotype (\%) (Gehalt mehrfach ungesättigter Fettsäuren /C22/ im Bullenfleisch nach Genotypen in \%)

\begin{tabular}{|c|c|c|c|c|c|}
\hline \multirow[b]{2}{*}{$\begin{array}{l}\text { Genotype } \\
\text { position* }\end{array}$} & \multirow[b]{2}{*}{$\mathrm{n}$} & \multirow[b]{2}{*}{ Fatty acids } & \multirow[b]{2}{*}{$\mathrm{LS}$ mean $\pm \mathrm{SE}$} & \multicolumn{2}{|c|}{ Statistical significance } \\
\hline & & & & $\mathrm{p}<0.05$ & $\mathrm{p}<0.01$ \\
\hline 1 & \multirow{8}{*}{211} & \multirow{8}{*}{ C22:4 } & $0.064 \pm 0.010$ & - & 8 \\
\hline 2 & & & $0.061 \pm 0.008$ & - & 8 \\
\hline 3 & & & $0.068 \pm 0.006$ & - & 8 \\
\hline 4 & & & $0.070 \pm 0.010$ & 8 & - \\
\hline 5 & & & $0.055 \pm 0.011$ & - & 8 \\
\hline 6 & & & $0.061 \pm 0.003$ & 7 & 7,8 \\
\hline 7 & & & $0.078 \pm 0.006$ & 6,8 & 6 \\
\hline 8 & & & $0.101 \pm 0.008$ & 4,7 & $1,2,3,5,6$ \\
\hline 1 & \multirow{8}{*}{211} & \multirow{8}{*}{ C22:5 } & $0.191 \pm 0.026$ & 2 & 6,8 \\
\hline 2 & & & $0.125 \pm 0.020$ & 1,8 & 7,8 \\
\hline 3 & & & $0.138 \pm 0.016$ & - & 7,8 \\
\hline 4 & & & $0.126 \pm 0.027$ & 7 & 8 \\
\hline 5 & & & $0.177 \pm 0.029$ & - & - \\
\hline 6 & & & $0.122 \pm 0.009$ & - & $1,7,8$ \\
\hline 7 & & & $0.198 \pm 0.015$ & 4 & 2,3,6,8 \\
\hline 8 & & & $0.300 \pm 0.021$ & 2 & $1,2,3,4,6,7$ \\
\hline 1 & \multirow{8}{*}{211} & \multirow{8}{*}{ C22:6 } & $0.125 \pm 0.015$ & - & 8 \\
\hline 2 & & & $0.101 \pm 0.012$ & - & 7,8 \\
\hline 3 & & & $0.093 \pm 0.009$ & - & 7,8, \\
\hline 4 & & & $0.084 \pm 0.016$ & - & 7,8 \\
\hline 5 & & & $0.110 \pm 0.018$ & - & 8 \\
\hline 6 & & & $0.102 \pm 0.005$ & - & 7,8 \\
\hline 7 & & & $0.146 \pm 0.009$ & - & 6,8 \\
\hline 8 & & & $0.191 \pm 0.013$ & - & $1,2,3,4,5,6,7$ \\
\hline
\end{tabular}

*/ See table 1

The differences in the content of fatty acids with 22 carbons -5 and 6 double bonds were more significant. Highly significant differences in the content of C22:5 were discovered among the Piemontese crossbreds $(0,300 \%)$ and all the others genotypes. Changes in the content of fatty acid C22:6 were similar; the highest content was detected in the group of the dual-purpose breed (C) x Pi-hybrids $(0.191 \pm 0.013 \%)$. The lowest contents of C22:6 of less than $0.1 \%$ were seen in the Bb- and Ba-hybrids. In a group of 102 slaughter bulls we studied the effect of the genotype on the content of positional and spatial isomers n-6 and n-3 of fatty acids C18:3 and C22:5 in the intramuscular fat of $m l t h$ (Table 4). Within the individual groups the differences in the content of the respective isomers (n-6 and n-3) of the fatty acid C18:3 were 
insignificant and the n-6/n-3 ratio ranged between $0.325(\mathrm{C})$ and $0.270(\mathrm{C} \mathrm{x} \mathrm{Pi})$. The breed that came closest to the Pi hybrids in terms of the ratio of the isomers of fatty acid C18:3 were $\mathrm{C}$ x Li crossbreds (0.2733). In contrast, a low proportion of isomers were detected in the $\mathrm{C} \mathrm{x} \mathrm{Bb}$ crossbreds (0.3193). In a smaller group of slaughter bulls we also studied the effect of the genotypes on the content of positional and spatial isomers C22:5 n-6 and C22:5 n-3, compared to the other fatty acids. The differences among the studied cattle genotypes were statistically insignificant $(p<0.05)$. In the intramuscular adipose tissue of mlth samples we determined a higher content of isomer C22:5 n-6. The C22:5 n-3 / C22:5 n-6 ratio was the highest in the control group (C) and in bulls - C x He and C x Ba (0.241). Dual-purpose cattle breeds (C) belong to genotypes with the highest content of isomers n-3 - C18:3 and C22:5.

Table 4

Content of isomers of polyunsaturated fatty acids in meat of bulls according to the genotype (\%) (Gehalt der Isomeren mehrfach ungesättigter Fettsäuren im Bullenfleisch nach Genotypen in \%)

\begin{tabular}{|c|c|c|c|c|}
\hline \multirow{2}{*}{$\begin{array}{l}\text { Genotype position } \\
\qquad / *\end{array}$} & \multirow{2}{*}{ Fatty acids } & \multirow{2}{*}{$\mathrm{LS}$ mean $\pm \mathrm{SE}$} & \multicolumn{2}{|c|}{ Statistical significance } \\
\hline & & & $\mathrm{p}<0.05$ & $\mathrm{p}<0.01$ \\
\hline 1 & \multirow{8}{*}{ C18:3 n-3 } & $0.424 \pm 0.031$ & - & - \\
\hline 2 & & $0.457 \pm 0.039$ & - & - \\
\hline 3 & & $0.470 \pm 0.039$ & - & - \\
\hline 4 & & $0,439 \pm 0,037$ & - & - \\
\hline 5 & & $0.477 \pm 0.039$ & - & - \\
\hline 6 & & $0.444 \pm 0.019$ & - & - \\
\hline 7 & & $0.479 \pm 0.022$ & - & - \\
\hline 8 & & $0.463 \pm 0.027$ & - & - \\
\hline 1 & \multirow{8}{*}{ C18:3 n-6 } & $0.138 \pm 0.006$ & - & - \\
\hline 2 & & $0.130 \pm 0.008$ & - & - \\
\hline 3 & & $0.145 \pm 0.008$ & 7 & 8 \\
\hline 4 & & $0.140 \pm 0,004$ & - & - \\
\hline 5 & & $0.139 \pm 0.008$ & - & - \\
\hline 6 & & $0.137 \pm 0.004$ & - & - \\
\hline 7 & & $0.131 \pm 0.004$ & 3 & - \\
\hline 8 & & $0.125 \pm 0.005$ & - & 3 \\
\hline 1 & \multirow{8}{*}{ C22:5 n-3 } & $0.216 \pm 0.026$ & - & - \\
\hline 2 & & $0.196 \pm 0.026$ & - & - \\
\hline 3 & & $0.149 \pm 0.026$ & - & - \\
\hline 4 & & $0.176 \pm 0.021$ & - & - \\
\hline 5 & & $0.170 \pm 0.013$ & - & - \\
\hline 6 & & $0.181 \pm 0.014$ & - & - \\
\hline 7 & & $0.204 \pm 0.018$ & - & - \\
\hline 8 & & $0.196 \pm 0.026$ & - & - \\
\hline 1 & \multirow{8}{*}{ C 22:5 n-6 } & $0.038 \pm 0.006$ & - & - \\
\hline 2 & & $0.035 \pm 0.006$ & - & - \\
\hline 3 & & $0.036 \pm 0.006$ & - & - \\
\hline 4 & & $0.031 \pm 0.004$ & - & - \\
\hline 5 & & $0.041 \pm 0.003$ & - & - \\
\hline 6 & & $0.035 \pm 0.003$ & - & - \\
\hline 7 & & $0.042 \pm 0.004$ & - & - \\
\hline 8 & & $0.035 \pm 0.006$ & - & - \\
\hline
\end{tabular}

*/ See table 1

The second studied effect of the content of polyunsaturated fatty acids was the age of the animals at the end of the fattening period. The effect of the age of the animals at the time of slaughter on the content of fatty acids was not significant. The determining coefficient $\left(r^{2}\right)$ was very low and that is why the share of the age on the accountable 
variation of the content of fatty acids was altogether insignificant. The contents of fatty acids were very balanced and the differences among groups of different age at the end of the fattening stage ( $<500$ days/ $<501$ days) were insignificant.

Another factor, which we analyzed and which affected the content of polyunsaturated fatty acids, was the weight of the carcasses of the slaughter bulls. As when we studied the effect of the slaughter age of the bulls on the development of the content of fatty acids, we detected no differences of notable significance in terms of the carcass weight. We did not discover any significant differences $(\mathrm{p}<0.05)$ among the subgroups of slaughtered bulls classified according to the carcass weight, and the determination coefficient $\left(\mathrm{r}^{2}\right)$ was very low. The trend that some fatty acids $(\mathrm{C} 18: 3$ and C18:3 n-3, C20:3 and acids with the longest carbon chain and C22:5 n-3) increase their content in association with increasing carcass weight was only adumbrated. The trend in the development of the contents of the other acids was reverse and was not statistically significant $(\mathrm{p}<0.05)$.

Table 5

Content of polyunsaturated fatty acids in meat of bulls according to the intramuscular fat content (\%) (Gehalt mehrfach ungesättigter Fettsäuren abhängig vom intramuskulären Fettgehalt des Bullenfleisches in \%)

\begin{tabular}{|c|c|c|c|c|c|}
\hline \multirow{2}{*}{\multicolumn{2}{|c|}{$\begin{array}{l}\text { Intramuscular fat (\%) /Group } \\
\text { Position }\end{array}$}} & \multirow{2}{*}{ Fatty acids } & \multirow{2}{*}{ LS mean $\pm \mathrm{SE}$} & \multicolumn{2}{|c|}{ Statistical significance } \\
\hline & & & & $\mathrm{p}<0.05$ & $\mathrm{p}<0.01$ \\
\hline$<1$ & 1 & \multirow{3}{*}{ C18:3 } & $0.379 \pm 0,029$ & - & - \\
\hline $1.1-2$ & 2 & & $0.421 \pm 0,024$ & - & - \\
\hline$<2.1$ & 3 & & $0.436 \pm 0,039$ & - & - \\
\hline$<1$ & 1 & \multirow{3}{*}{ C20:3 } & $0.138 \pm 0,008$ & - & 2,3 \\
\hline $1.1-2$ & 2 & & $0.104 \pm 0,007$ & - & 1 \\
\hline$<2.1$ & 3 & & $0.082 \pm 0,012$ & - & 1 \\
\hline$<1$ & 1 & \multirow{3}{*}{ C20:4 } & $0.550 \pm 0,038$ & - & 2,3 \\
\hline $1.1-2$ & 2 & & $0.357 \pm 0,033$ & - & 1 \\
\hline$<2.1$ & 3 & & $0.266 \pm 0,052$ & - & 1 \\
\hline$<1$ & 1 & \multirow{3}{*}{ C20:5 } & $0.116 \pm 0,009$ & - & 2,3 \\
\hline $1.1-2$ & 2 & & $0.103 \pm 0,007$ & 3 & 1 \\
\hline$<2.1$ & 3 & & $0.069 \pm 0,013$ & 2 & 1 \\
\hline$<1$ & 1 & \multirow{3}{*}{ C20:6 } & $0.053 \pm 0,003$ & - & 3 \\
\hline $1.1-2$ & 2 & & $0.047 \pm 0,002$ & 3 & - \\
\hline$<2.1$ & 3 & & $0.038 \pm 0,004$ & 2 & 1 \\
\hline$<1$ & 1 & \multirow{3}{*}{ C22:4 } & $0.090 \pm 0,004$ & - & 2,3 \\
\hline $1.1-2$ & 2 & & $0.068 \pm 0,003$ & 3 & 1 \\
\hline$<2.1$ & 3 & & $0.052 \pm 0,006$ & 2 & 1 \\
\hline$<1$ & 1 & \multirow{3}{*}{ C22:5 } & $0.181 \pm 0,011$ & - & 2,3 \\
\hline $1.1-2$ & 2 & & $0.142 \pm 0,010$ & - & 1 \\
\hline$<2.1$ & 3 & & $0.129 \pm 0,017$ & - & 1 \\
\hline$<1$ & 1 & \multirow{3}{*}{ C22:6 } & $0.138 \pm 0,007$ & - & 2,3 \\
\hline $1.1-2$ & 2 & & $0.116 \pm 0,006$ & - & 1 \\
\hline$<2.1$ & 3 & & $0.104 \pm 0,010$ & - & 1 \\
\hline$<1$ & 1 & \multirow{3}{*}{ C18:3 n-3 } & $0.526 \pm 0,022$ & - & 2,3 \\
\hline $1.1-2$ & 2 & & $0.462 \pm 0,016$ & 3 & 1 \\
\hline$<2.1$ & 3 & & $0.391 \pm 0,024$ & 2 & 1 \\
\hline$<1$ & 1 & \multirow{3}{*}{ C18:3 n-6 } & $0.149 \pm 0,004$ & - & 2,3 \\
\hline $1.1-2$ & 2 & & $0.135 \pm 0,003$ & 3 & 1 \\
\hline$<2.1$ & 3 & & $0.121 \pm 0,005$ & 2 & 1 \\
\hline$<1$ & 1 & \multirow{3}{*}{ C22:5 n-3 } & $0.261 \pm 0,014$ & - & 2,3 \\
\hline $1.1-2$ & 2 & & $0.171 \pm 0,010$ & - & 1 \\
\hline$<2.1$ & 3 & & $0.122 \pm 0,016$ & - & 1 \\
\hline$<1$ & 1 & \multirow{3}{*}{ C22:5 n-6 } & $0.050 \pm 0,003$ & - & 2,3 \\
\hline $1.1-2$ & 2 & & $0.036 \pm 0,002$ & 3 & 1 \\
\hline$<2.1$ & 3 & & $0.024 \pm 0,004$ & 2 & 1 \\
\hline
\end{tabular}


Very frequently discussed in professional and scientific literature is the correlation between the content of fatty acids and the relative proportion of the content of intramuscularly adipose tissue in the meat of different jointed parts of the cattle carcass. In the present study we summarized results of analysis of the Musculus longissimus dorsi; the slaughter bulls were divided into 3 groups based on the content of intramuscular adipose tissue (Table 5).

With increased proportion of fat the content of acid C18:3 increased insignificantly, i.e. from $0.379 \%$ (group with less than $1 \%$ fat) to $0.436 \%$ (group with more than $2 \%$ fat). As the fat content of the meat increased the content of acid increased $15.04 \%$.

The proportion of the evaluated factor on the total accountable variance of acid C18:3 is very low and insignificant. The differences in the contents of the other fatty acids were highly significant and the increase in the content of intramuscularly adipose tissue went together with a significant $(p<0.01)$ reduction in the content of the fatty acid. Differences between the $2^{\text {nd }}$ and $3^{\text {rd }}$ group (fat content 1.1-2.0 and more than 2.1 $\%$, respectively) were significant in some acids only at the level of $\mathrm{p}<0.05$. In terms of fatty acids the most marked reduction in their content in dependence on the muscle fat content was that of acids C20:4 (-51.6\%), C20:3 (-40.6\%), C20:5 (-40.52\%) and C22:4 $(-42.22 \%)$. The reduction of acids with the longest carbon chain (C22) in dependence upon the fat of the muscles, with the exception of C22:4, was lower (-28.73\% / C22:5; $-24.63 \%$ / C22:6). The differences in both isomers of linolenic acid among the partial groups of bulls were significant $(\mathrm{p}<0.05$ and $\mathrm{p}<0.01)$.

\section{Discussion}

In the present study significant changes in the content of most of the analyzed fatty acids were determined among hybrid types of cattle. Most significant was the effect of the crossbreds on the content of polyunsaturated fatty acids and was evident in the changes of the contents of C18:3, C20:4, C22:4, C22:5 and C22:6. The content of C18:3 increased significantly in the meat of $\mathrm{C} \times \mathrm{Pi}$ crossbreds, while the lowest content was quantified in $\mathrm{C}$ x Bb crossbred bulls. MOJTO et al. (1995) reported insignificant differences in the content of the above acid in the meat of bulls of the Slovakian breeds. MIR et al. (2000) discovered insignificant differences in the content of this fatty acid in the intramuscular adipose tissue of British and European hybrids and crosses with the Wagyu breed. In their studies on the effect of the sex and breed on changes in the content of fatty acids of the Jersey and Limousine breeds, including their reciprocal crosses, MALAU et al. (2000) discovered no significant differences in the total content of polyunsaturated fatty acids either. However EICHORN et al. (1985) reported more significant differences in the content of the fatty acids in the $m$. semitendinosus, triceps brachii, longissimus and subcutaneous adipose tissue between the sexes, crosses of beef breeds (Angus, Hereford, Brahman) with Limousine bulls. The differences among the above crosses were highly significant $(p<0.01)$. ZEMBAYASHI et al. (1995) monitored insignificant differences in average values of acid C20:3 between the Japanese Black cattle and its crosses with the Holstein, Japanese Black and Charolais breeds. Also WEGLARZ et al. (1999) and HOLLO et al. (2005) monitored a significant effect $(p<0.05)$ of the genotypes of cattle on the content of the C18:3 acid in the meat of Black Pied cattle and its crosses with Italian breeds (Piemontese, Marchigiana and Chianino) respectively Hungarian Grey bulls. 
Similar to our present results they discovered a higher percentage of polyunsaturated fatty acids in Piedmont crossbreds. MATTHES et al. (1995) ad NÜRNBERG et al. (1999) found that the breed had a significant effect (Galoway, German Holstein and Belgian Blue) on the changes in and the content of C22:5n-3. However the differences among genotypes of slaughter bulls in the content of C22:5 n-6 were insignificant and the lower values ranged between $0.042(\mathrm{C} \mathrm{x} \mathrm{Li})$ and $0.031 \%(\mathrm{C} \mathrm{x} \mathrm{Bb})$. The differences in the content of the respective fatty acids confirmed the conclusions published in the work of De SMET et al. (2004) who drew attention to the fact that the effect of genetic factors on the profile of fatty acids are of greater importance. Although the effect of these factors on the composition of fatty acids in the intramuscularly adipose tissue of cattle is lower than the effect of dietary factors, it cannot be underestimated. Pursuant to these conclusions we determined a predominantly positive effect on the structure of polyunsaturated fatty acids in the beef of some of the hybrid types of cattle (based on the breed of the sire). We also monitored a relatively high content of a number of polyunsaturated fatty acids in the control group, i.e. the Bohemian Spotted cattle. Bulls of Aquitaine Blond and Belgian Blue crossbreds also belong to commercial types and have a high level of acid C20:5. Basing on the commercial type we found no significant differences between isomers n- 6 and n-3 of acids C18:3 and C22:5, the same as when evaluating the age of the bulls at the age of slaughter and the carcass weight. The content of intramuscular adipose tissue had a significant to highly significant effect on the content of the major part of polyunsaturated fatty acids. A higher deposition of fat in the muscles resulted in a significant reduction of the content of polyunsaturated fatty acids, including isomers n-3 and n-6 of acids C18:3 and C 22:5.

\section{References}

CHAMBAZ, A.; KREUZER, M.; SCHEEDER, R. L.; DUFEY, P. A.:

Characteristics of steers of six beef breeds fattened from eight month of age and slaughtered at a target level of intramuscular fat. II: Meat quality. Arch. Tierz., Dummerstorf 44 (2001) 5, 473-488

DANNENBERGER, D.; NUERNBERG, G.; SCOLLAN, N.; SCHABBEL, W.; STEINHART, H.; ENDER, K.; NUERNBERG, K.:

Effect of diet on the deposition of n-3 fatty acids, conjugated linoleic and C18:1 trans fatty acid isomers in muscle lipids of German Holstein bulls. Journal of Agricultural and Food Chemistry, 52 (2004), 6607-6615

De SMET, S.L.; RAES, K.; DEMEYER, D.:

Meat fatty acid composition as affected by fatness and genetic factors: a review. Animal Research, 53 (2004), MAR-APR, 81-98

EICHORN, J.M.; BAILEY, C.M.; BLOMQUIST, G.J.:

Fatty acid composition of muscle and adipose tissue from crossbred bulls and steers. J. Anim. Sci., 61 (1985), 892-904

ENDER, K.; NŮRNBERG, K.; PAPSTEIN, H.J.: Die zwei Seiten des Fettes - eine Standortbestimmung. Arch. Tierz., Dummerstorf 40 (1997) 1, 35-45

FRELICH, J.; VORISKOVA, J.; KUNIK, J.; KVAPILIK, J.: Mast- und Schlachtleistungen von Bullen aus Gebrauchskreuzungen tschechischer Rinderrassen mit Fleischrinderrassen. Arch. Tierz., Dummerstorf 41 (1998) 6, 533-544

HOLLO, G.; NUERNBERG, K.; REPA, 1.; HOOLO, I.; SEREGI, J.; POHN, G.; ENDER, K.:

Der Einfluss der Fütterung auf die Zusammensetzung des intramuskulären Fettes des Musculus longissimus und verschiedener Fettdepots von Jungbullen der Rassen Ungarisches Grauvieh und Holstein Friesian. I. Mitt.: Fettsäurezusammensetzung. Arch. Tierz., Dummerstorf 48 (2005), 537-546

KREUZER, M.; GERHARDY, H.; OSSOWSKI, D.; VOSS, G. E. M.:

Improved storage and dietetic properties of carcass fat tissues in growing Holstein as well as Charolais x Holstein bulls fed full-fat rapeseed. Arch. Tierz., Dummerstorf 38 (1995), 163-175

LABORDE, F. L.; MANDELL, I. B.; TOSH, J. J.; WILTON, J. W.; BUCHANAN-SMITH, J. G.: 
Breed effects on growth performance, carcass characteristics, fatty acid composition, and palatability attributes in finishing steers. Journal of Animal Science, 79 (2001) 2, 355-365

LEIBETSEDER, J.:

Beeinflussung der Zusammensetzung tierischer Fette durch die Fütterung. Arch. Tierz., Dummerstorf 39 (1996), 333-345

MALAU-ADULI, A. E. O.; EDRISS, M. A.; SEIBERT, B. D.; BOTTEMA ,C. D. K.; PITCHFORD, W. S.:

Breed differences and heterosis in triacylglycerol fatty acid composition of bovine adipose tissue. J. Anim. Physiol. and Anim. Nutr., 83 (2000), 106-112

MATTHES, H. D.; NÜRNBERG, K.; WEGNER, J.; BITTNER, G.; JENTSCH, W.; DERNO, M.:

Schlachtkörperzusammensetzung restriktiv gefütterter Jungbullen unterschiedlich adaptierter Rinderrassen. Arch. Tierz., Dummerstorf 39 (1996) 1, 17-24

MIR, Z.; PATERSON, L.J.; MIR, P.S.:

Fatty acid composition and conjugated linoleic acid content of intramuscular fat in crossbred cattle with without Wagyu genetic fed barley- based diet. Canadian Journal of Animal Science, 80 (2000) Mar, 1, 195-197

MOJTO, J.; CHRENEK, J.; PALANSKÁ, O.; KMEŤ, J.; ZAUJEC, K.; PAVLIČ, M.:

Nutritional and technological quality of meat and fat of slaughter bulls of Holstein breed and crosses with Belgian Blue. Cz. J. Anim. Sci. (Živočišná výroba),43 (1998), 483-487

MOJTO, J.; PALANSKÁ, O.; CHRENEK, J.; ONDREJIČKA, R.; ČUBOŇ, J.; NOSÁĹ, V.:

Content of the fatty acids and cholesterol in intramuscular fat of slaughter bulls of different genotypes. Cz. J. Anim. Sci. (Živočišná výroba), 40 (1995), 273-276

NÜRNBERG, K.; ENDER, B.; PAPSTEIN, H.J.; WEGNER, J.; ENDER, K.; NÜRNBERG, G. : Effects of growth and breed on the fatty acid composition of the muscle lipids in cattle. Z. Lebensm. Unters Forsch. A (1999), 208: 332-335

OPRZADEK, J.; OPRZADEK, A.:

Modifications of fatty acids composition in ruminants. Medycyna weterynaryjna, 59 (2003) JUN, 6, 492-495

PALANSKÁ, O.; NOSÁĹ, V.; ONDREJIČKA, R.; ČUBOŇ, J.:

The quality of intramuscular fat of beef bulls by the different growth intensity and slaughter weight. J. Farm. Anim. Sci., 56 (1993), 105-110

PFEUFFER, M.:

Physiologic effects of individual fatty acids in animal and human body, with particular attention to coronary heart disease risk modulation. Arch. Tierz., Dummerstorf 44 (2001) 1, 89-98

RAES, K.; De SMET, S.; BALCAEN, A.; CLAEYS, E.; DEMEYER, D.:

Effect of diets rich in N-3 polyunsaturated fatty acids on muscle lipids and fatty acids in Belgian Blue double-muscled young bulls. Reproduction Nutrition Development, 43 (2003) 4, 331-345

RAES, K.; De SMET, S.; DEMEYER, D.:

Effect of dietary fatty acids on incorporation of long chain polyunsaturated fatty acids and conjugated linoleic acid in lamb, beef and pork meat: a review. Animal Feed Science and Technology, 113 (2004), 199-221

RULE, D. C.; MACNEIL, M. D.; SHORT, R. E.:

Influence of Sire Growth Potential, Time on Feed, and Growing - Finishing Strategy on Cholesterol and Fatty Acids of the Ground Carcass and Longissimus Muscle of Beef Steers. J. Anim. Sci., 75 (1997), 1525-1533

SAMI, A. S.; AUGUSTINI, C.; SCHWARZ, F.J.:

Effect of feeding intensity and time on feed on intramuscular fatty acid composition of Simmental bulls. Journal of Animal Physiology and Animal Nutrition, 88 (2004) JUN, 179-187

STEEN, R.W.J.; LAVERY, N.P.; KILPATRICK, D.J.:

Effects of pasture and high-concentrate diets on the performance of beef cattle, carcass composition at equal growth rates, and the fatty acid composition of beef. New Zealand Journal of Agricultural Research, 46 (2003) JUN, 69-81

ŠUBRT, J.; PITRUNOVÁ, H.; ŽUPKA, Z.; VÁVROVÁ, M.; VÁVRA, S.: Influence of genotype of bulls on the composition of the fatty acids in Musculus longissimus thoracis and kidney fat. Cz. J. Anim. Sci. (Živočišná výroba), 36 (1991) 2, 203-210

ŠUBRT, J.; FIALOVÁ, M.; DIVIŠ V.:

The influence of commercial of bulls on fatty acid composition in meat. Czech Journal Animal Science, 46 (2001) 11, 496-502

TSUNEISCHI, E.; TAKIMOTO, Y.; NISHIMURA, K.; TAKEDA, H.:

Fatty Acid Composition of Triacylglycerol and Phospholipid in Various muscle Tissues of Beef Cattle. Japn. J. Zootech. Sci., 58 (1987) 11, 919-926

WEGLARZ, A.; GARDZINA, E.; ZAPLETAL, P.; SZAREK, J.: 
Cholesterol levels and fatty acids composition in meat of young bulls from Black-and-White cows and Italian beef breeds. Coll. Sci. Papers, Faculty of Agriculture in České Budějovice, Series for Animal Science, 16 (1999) 1, 15-20

WOOD, J.D.; RICHARDSON, R.I.; NUTE, G.R.; FISHER, A.V.; CAMPO, M.M.; KASAPIDOU, E.; SHEARD, P.R.; ENSER, M.:

Effects of fatty acids on meat quality: a review. Meat Science, 66 (2004) JAN, 1:21-32

ZEMBAYASHI, W.; NISHIMURA, K.; LUNTT, D.K.; SMITH, S.B.:

Effect of Breed Type and Sex on the Fatty Acid Composition of Subcutaneous and Intramuscular Lipids of Finishing Steers and Heifers. J. Anim. Sci., 73 (1995), 3325-3332

Received: 2005-10-12

Accepted: 2006-04-20

Corresponding Author

Prof. Ing. JAN ŠUBRT, CSc.

Mendel University of Agriculture and Forestry Brno,

Department of Animal Breeding,

Zemědělská 1

61300 BRNO

CZECH REPUBLIC

E-Mail: subrt@ mendelu.cz 